\title{
Performance of Nickel-Coated Manganese Steel in High-Chloride Low-Sulphate Seawater Environments
}

\author{
Olorunniwo, O. E. ${ }^{1 *}$, Atanda, P. O. ${ }^{1}$, Akinluwade, K. J. ${ }^{1,2}$ Adetunji, A.R. ${ }^{1,2}$, and \\ Oluwasegun, K.M. ${ }^{1}$ \\ ${ }^{1}$ Department of Materials Science \& Engineering Obafemi Awolowo University Ile-Ife \\ ${ }^{2}$ National Agency for Science \& Engineering Infrastructure (NASENI), Abuja \\ *Corresponding author: oolorunn@oauife.edu.ng
}

\begin{abstract}
This work investigated the service performance of nickel-coated manganese steel in both normal high-chloride (clean) and low-sulphate high-chloride (polluted) seawater environments (typical offshore oil and gas production environments). Structural manganese steels coated with nickel together with the control were tested for corrosion characteristics using the weight loss method. It was found that the nickel coat was able to resist corrosion overtime via spontaneous formation of passive oxide films at ambient temperatures. Analysis of resulting corrosion rates underscored the viability of nickel coating at inhibiting severe corrosion owing to the harsh chloride-and sulphate-containing seawater typical of the oil and gas production environments.
\end{abstract}

Keywords: passive oxide, corrosion, high-chloride low-sulphate seawater, manganese steel, electroplating,

\section{INTRODUCTION}

It is estimated that industry spends $\$ 276$ billion annually on corrosion. These costs arise from a variety of areas. Prevention, monitoring, and repair are the main contributors to this high amount and these values do not even include down time as a result of corrosion $[1,6]$.

Corrosion is the deterioration of a material or its properties in a given service environment. It is also the partial or complete wearing away, dissolving, or softening of any substance by chemical or electrochemical reaction with its environment. The term corrosion specifically applies to the gradual action of natural agents, such as air or salt water, on metals. It is a state of deterioration in metals caused by oxidation or chemical action [10]. The basic corrosion cell is formed by two dissimilar metals immersed in an electrolyte joined by a conductor, One electrode will tend to corrode more readily than the other and is called the anode. Natural systems often place the machine part as the anode while the prevailing environment makes up the electrolyte $[8,9]$. 
The oil industry consists of the upstream businesses of exploration \& production and gas \& power and the downstream businesses of oil products, chemicals and oil sands. Corrosion attacks every component at every stage in the life of every oil and gas field. At the drilling stage (which is about the first stage in production), oxygen-contaminated fluids are first introduced. Water and carbon-dioxide-produced or injected for secondary recovery - can cause severe corrosion of completion strings. Hydrogen sulphate in the plant effluents poses severe environmental hazards. This makes the surrounding water and atmosphere hostile to metallic tools and parts [4, 7].

Several established and emerging technologies for corrosion evaluation and monitoring abound. Established technologies include measuring environmental conditions, exposing material coupons to corrosive media, and using electrical resistance, linear polarization resistance, and galvanic probes. Emerging technologies include the use of advanced electrochemical testing techniques and the application of specialized probes for stress-corrosion cracking and pitting corrosion [4, 5, 9]. Since it is almost impossible to prevent corrosion, it is becoming more apparent that monitoring and controlling the corrosion rate may be the only economical solution. The oil industry has invested heavily in material and personnel to try to tame corrosion and prevent ferrous tools from returning to their natural state. New oil fields benefit from predevelopment planning and the growing knowledge of all aspects of corrosion control and monitoring [2. 3]. A large volume of research work has been done to proffer solution to corrosion phenomenon. The present work understudies the performance of nickel-coated manganese steel in two environments which represent the oil and gas production environments of normal high-chloride (clean) and low-sulphate high-chloride (polluted) seawater.

\section{MATERIALS AND METHOD}

\subsection{Description of Steel Samples}

The steel material used for this experiment is ST60Mn steel obtained from the standard stock with the chemical composition (wt\%) of carbon 0.35-0.42, silicon 0.20-0.30, manganese 0.901.20 , phosphorus 0.04 , sulphur 0.25 , copper 0.10 , chromium 0.10 , nickel 0.10 ; the balance being iron. From this steel, 30 pieces of about $10 \mathrm{~mm}$ square samples were prepared.

\subsection{Corrosion Media}

Two corrosive environments were prepared:

(i) High chloride seawater environment from the Atlantic Ocean.

(ii) Simulated low-sulphate high-chloride environment obtained by adding $0.015 \mathrm{M} \mathrm{Na}_{2} \mathrm{SO}_{4}$ to seawater sourced from the Atlantic Ocean.

In general, these two environments represent the oil and gas production environment of normal high-chloride (clean) and low-sulphate high-chloride (polluted) seawater environments. 


\subsection{Electroplating}

To obtain good adhesion and brightness of the nickel coat on the substrates, the nickel solution for a 3 litres plating bath was prepared using $600 \mathrm{~g}$ of nickel sulphate, $120 \mathrm{~g}$ of nickel chloride, $120 \mathrm{~g}$ of boric acid, $60 \mathrm{ml}$ of formaldehyde and 3 litres of distilled water. Using a nickel anode, the steel samples were electroplated for 40 and 50 minutes respectively. The electrolyte having being preheated to $50^{\circ} \mathrm{C}$. After electrolysis the specimens were removed, rinsed in distilled water and left to cool off in sawdust. Only 20 samples were electroplated while the remaining 10 were left as control. After electroplating, the initial weights of all samples were measured and recorded using a digital weighing balance.

\subsection{Corrosion Test}

A group of three samples (comprising an uncoated sample and two samples each coated for 40 and 50 minutes respectively) was suspended from strings and completely immersed in highchloride seawater contained in clean HDPE bowls for 6 days. After this period of complete immersion, the samples were removed, cleaned and weighed (final weight). This was repeated for another four groups but with immersion durations of 12, 18, 24 and 30 days respectively. In the same vein, five groups of samples were suspended from strings and completely immersed in high-chloride low-sulphate seawater for 6, 12, 18, 24 and 30 days respectively. The final weights were measured and recorded.

\subsection{Corrosion Rate Measurement}

Corrosion rate measurement was obtained from the weight loss method using the standard corrosion rate formula.

$C \cdot R .=\frac{k W}{D A T}$

Where,

$\mathrm{W}=$ weight loss $(\mathrm{g}) ; \mathrm{D}=$ density $\left(\mathrm{g} / \mathrm{cm}^{3}\right) ; \mathrm{A}=$ Area $\left(\mathrm{cm}^{2}\right) ; \mathrm{T}=$ Time (hrs)

$\mathrm{K}=$ corrosion constant which will depend on the dimension desired for the corrosion rate $(8.76 \mathrm{x}$ $10^{4}$ for $\mathrm{mm} /$ year).

\section{RESULTS AND DISCUSSION}

\subsection{Trend of Corrosion Rate}

Corrosion rates for curves of Figure 1 decrease non-uniformly with time for any given sample. Each corrosion rate curve is characterized with an initial peak owing to rapid interaction between the samples and their environment. Curves of Figure 2 also manifest similar initial peaks. Beyond six days, the rates of corrosion fall significantly. This rapid decline is due to prompt formation of passivating oxide films on the surface of immersed samples. It was observed that 
the electrodeposited nickel coat on the steel gave it a protection against corrosion. The passivating film which builds up on the surfaces of the samples are actually corrosion products which serve to inhibit further corrosion.

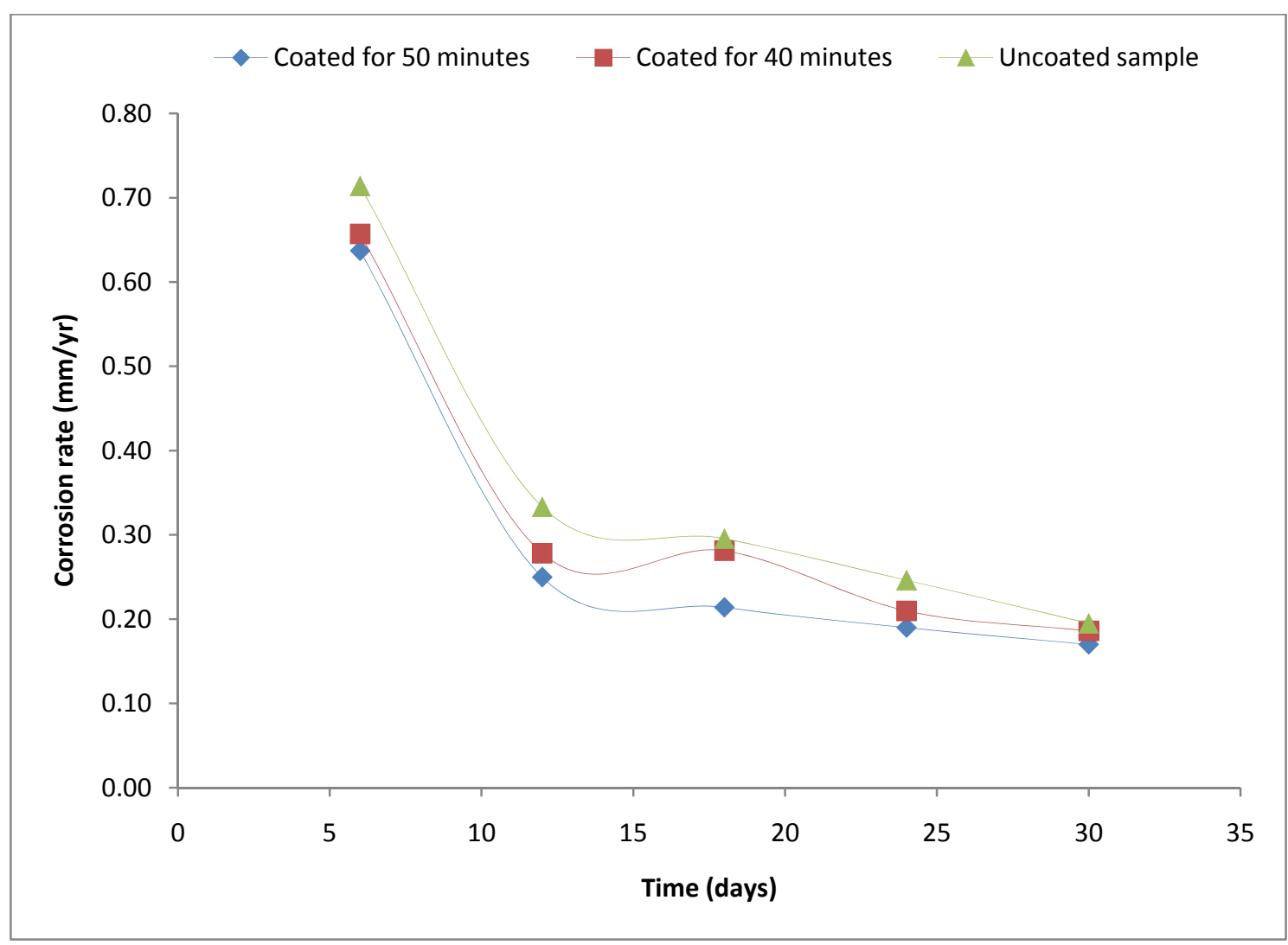

Figure 1: Corrosion rates of samples immersed in high-chloride seawater as a function of time

Beginning from 14 days down to 30 days the curves of corrosion rates of all the samples attempt to stabilize to a linear horizontal trend with a gentle slope. The curves of Figure 2 show a steeper slope than those of Figure 1 suggesting higher corrosion rates in the samples subjected to highchloride low-sulphate environment. This observation again bring to the fore the more severe corrosion tendency of dissolved sulphur polluted seawater.

\subsection{Corrosion Rates in High-Chloride Environment versus High Chloride Low-Sulphate Environment}

The initial corrosion rates (at six days) is higher for all the samples in high-chloride low-sulphate seawater environment than in high chloride seawater environment. Although the active corrosion products in seawater are the dissolved salts of which sodium chloride is chief, the presence of sulphur readily exacerbates corrosion as is demonstrated in this work. On the average, judging from Tables 1 and 2, the corrosion rate is increased by $5-25 \%$ by the presence of dissolved sulphur even at a low concentration for uncoated samples while the nickel coating reduced this corrosion rate to a maximum of $7-10 \%$. 


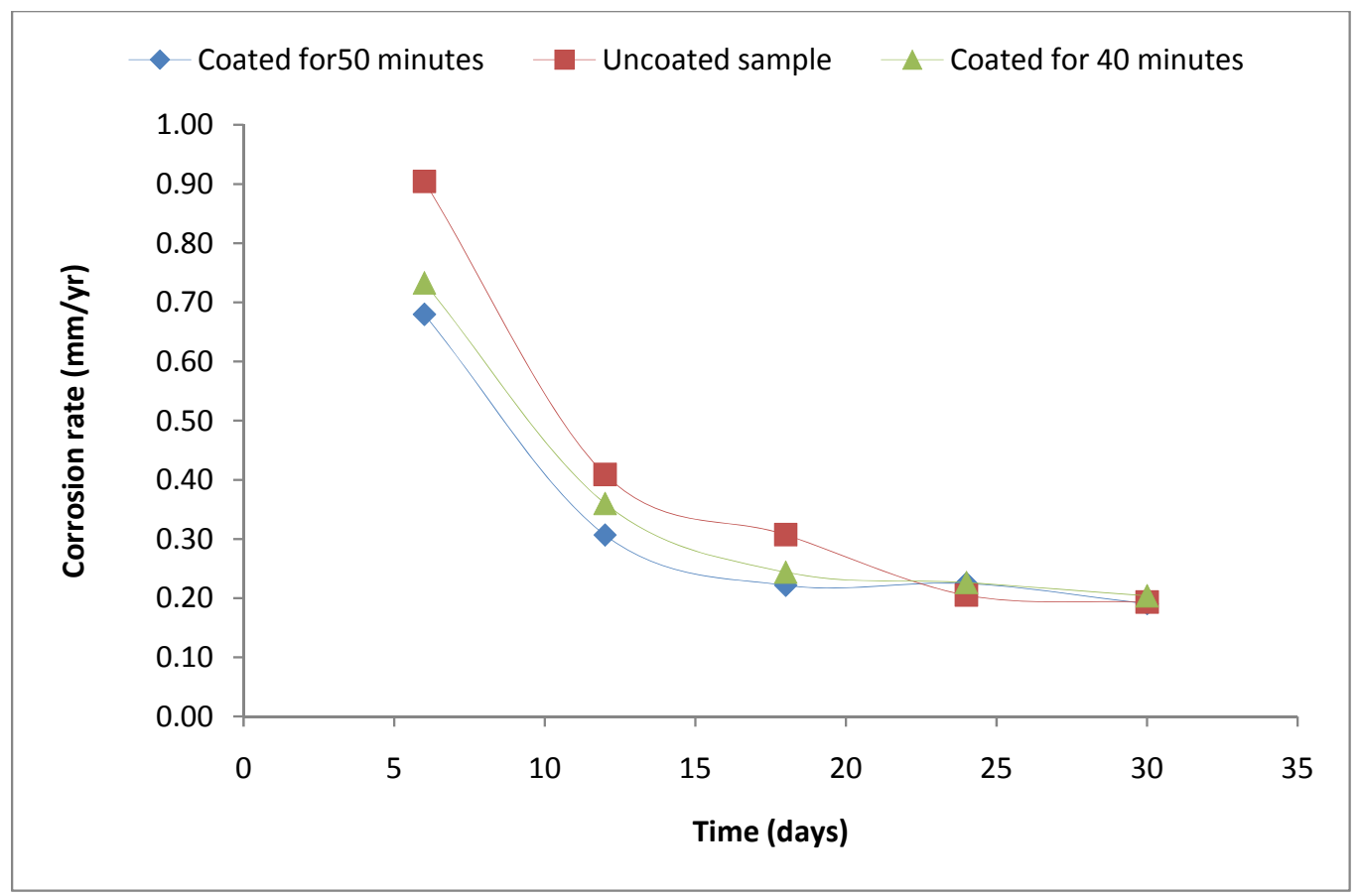

Figure 2: Corrosion rates of samples immersed in high-chloride low-sulphate seawater as a function of time

Table 1: Corrosion rates of samples immersed in high-chloride seawater

\begin{tabular}{|c|c|c|c|c|c|c|c|}
\hline \multicolumn{2}{|c|}{ Sample } & \multirow{2}{*}{$\begin{array}{c}\text { Area } \\
\left.\mathbf{( c m}^{2}\right)\end{array}$} & \multirow{2}{*}{$\begin{array}{r}\begin{array}{r}\text { Initial } \\
\text { weight ( }\end{array} \\
11.157\end{array}$} & \multirow{2}{*}{$\begin{array}{c}\begin{array}{c}\text { Final } \\
\text { weight ( }\end{array} \\
11.091\end{array}$} & \multirow{2}{*}{$\begin{array}{r}\text { Weigh } \\
\text { loss (g) }\end{array}$} & \multirow{2}{*}{$\begin{array}{c}\text { Day: } \\
6\end{array}$} & \multirow{2}{*}{$\begin{array}{r}\text { Time } \\
\text { (hrs) }\end{array}$} \\
\hline & $\mathrm{F}$ & & & & & & \\
\hline 焉 & G & 6.67 & 9.260 & 9.203 & 0.057 & 12 & 288 \\
\hline $0 \sum$ & $\mathrm{H}$ & 7.92 & 12.562 & 12.472 & 0.090 & 18 & 432 \\
\hline 岇心 & I & 6.97 & 10.971 & 10.883 & 0.088 & 24 & 576 \\
\hline & $\mathrm{J}$ & 7.36 & 11.459 & 11.367 & 0.092 & 30 & 720 \\
\hline \multirow{5}{*}{ 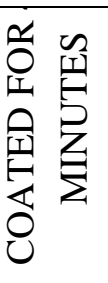 } & $\mathrm{F} 1$ & 6.41 & 9.053 & 8.999 & 0.054 & 6 & 144 \\
\hline & G1 & 6.59 & 9.072 & 9.025 & 0.047 & 12 & 288 \\
\hline & $\mathrm{H} 1$ & 7.12 & 10.463 & 10.386 & 0.077 & 18 & 432 \\
\hline & I1 & 6.32 & 8.350 & 8.282 & 0.068 & 24 & 576 \\
\hline & $\mathrm{J} 1$ & 6.54 & 8.370 & 8.292 & 0.078 & 30 & 720 \\
\hline \multirow{5}{*}{ 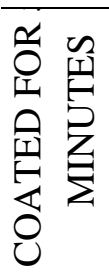 } & $\mathrm{F} 2$ & 6.12 & 8.017 & 7.967 & 0.050 & 6 & 144 \\
\hline & $\mathrm{G}^{-}$ & 7.65 & 8.088 & 8.039 & 0.049 & 12 & 288 \\
\hline & $\mathrm{H}_{2}^{-}$ & 6.44 & 8.309 & 8.256 & 0.053 & 18 & 432 \\
\hline & $\mathrm{I} 2$ & 7.29 & 8.574 & 8.503 & 0.071 & 24 & 576 \\
\hline & $\mathrm{J} 2$ & 8.17 & 12.718 & 12.629 & 0.089 & 30 & 720 \\
\hline
\end{tabular}


Table 2: Corrosion rates of samples immersed in high-chloride low-sulphide seawater

\begin{tabular}{|c|c|c|c|c|c|c|c|c|}
\hline San & ple & $\begin{array}{l}\text { Area } \\
\left(\mathrm{cm}^{2}\right)\end{array}$ & $\begin{array}{c}\text { Initial } \\
\text { weight } \\
\text { (g) }\end{array}$ & $\begin{array}{c}\text { Final } \\
\text { weight } \\
\text { (g) }\end{array}$ & $\begin{array}{l}\text { Weight } \\
\text { loss (g) }\end{array}$ & Days & $\begin{array}{l}\text { Time } \\
\text { (hrs) }\end{array}$ & $\begin{array}{c}\text { Corrosion } \\
\text { rate } \\
(\mathrm{mm} / \mathrm{yr})\end{array}$ \\
\hline & $\mathrm{A}$ & 5.95 & 11.486 & 11.417 & 0.069 & 6 & 144 & 0.9044 \\
\hline 덥 & B & 7.91 & 12.623 & 12.540 & 0.083 & 12 & 288 & 0.4092 \\
\hline 岁 & $\mathrm{C}$ & 7.70 & 12.001 & 11.910 & 0.091 & 18 & 432 & 0.3072 \\
\hline z & $\mathrm{D}$ & 7.60 & 9.272 & 9.192 & 0.080 & 24 & 576 & 0.2052 \\
\hline & $\mathrm{E}$ & 5.96 & 7.500 & 7.426 & 0.074 & 30 & 720 & 0.1937 \\
\hline 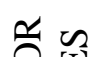 & A1 & 7.66 & 11.802 & 11.730 & 0.072 & 6 & 144 & 0.7331 \\
\hline 玒出 & B1 & 7.69 & 12.365 & 12.294 & 0.071 & 12 & 288 & 0.3600 \\
\hline 될 & C1 & 6.18 & 8.218 & 8.160 & 0.058 & 18 & 432 & 0.2440 \\
\hline & D1 & 6.89 & 9.902 & 9.822 & 0.080 & 24 & 576 & 0.2264 \\
\hline & E1 & 7.19 & 10.482 & 10.388 & 0.094 & 30 & 720 & 0.2039 \\
\hline$\cong$ n & A2 & 6.77 & 9.218 & 9.166 & 0.052 & 6 & 144 & 0.5990 \\
\hline 项 & B2 & 5.85 & 7.676 & 7.630 & 0.046 & 12 & 288 & 0.3066 \\
\hline 되 & $\mathrm{C} 2$ & 6.45 & 8.707 & 8.652 & 0.055 & 18 & 432 & 0.2217 \\
\hline & D2 & 6.42 & 8.815 & 8.741 & 0.074 & 24 & 576 & 0.2247 \\
\hline & E2 & 5.97 & 7.989 & 7.916 & 0.073 & 30 & 720 & 0.1907 \\
\hline
\end{tabular}

Many aqueous corrosion problems may be handled by using nickel and its alloys. The nickel coat has a good resistance to corrosion at ambient temperatures to high chloride and low sulphate seawater environments. Nickel spontaneously forms passive oxide films upon exposure to seawater at ambient temperature. This film helps to provide useful corrosion resistance which subsequently reduces corrosion rate overtime.

\section{CONCLUSION}

The following conclusions can be drawn from the experiment described above.

1. High-chloride low-sulphate seawater (polluted) environments are more corrosive than highchloride (clean) seawater environments.

2. Sulphate pollution in seawater increases corrosion rate of manganese steels by $5-25 \%$ for uncoated samples and this is reduced to $7-10 \%$ by electrodeposited nickel coating.

3. A thicker coat of electrodeposited nickel provides better corrosion resistance through formation of passivating oxide layers at the surface of the steels. 


\section{REFERENCES}

[1] Schremp, F. W. (1982). Corrosion Prevention for Off-shore Platforms. Paper SPE 9986, presented at the SPE International Petroleum Exhibition and Technical Symposium, Beijing, China, March 18-26.

[2] Maxwell, S. (1986). Assessment of Sulphide Control Risks in Off-shore Systems by Biological Monitoring, SPE Production Engineering 1, no. 5, pp 363-368.

[3] Tsujino, B., and Oki, T. (1989) Galvanic Mild-Steel Corrosion in Methanol and Corrosion Monitoring. Corrosion Engineering, Vol. 38, No.8, pp. 433-440.

[4] Alvarado, R. M., and Arnold, C. G. (1986). Computerized Corrosion Data Monitoring in a Chemical Process Plant, Paper 69, Corrosion 86, NACE, Houston.

[5] Asperger, R. G., and Hewitt, P. G (1986) Real-Time Electronic Monitoring of a Pitted and Leaking Gas Gathering Pipeline. Materials Performance, Vol. 25, No.9, pp. 47-57.

[6] Christensen, C., Maahn, E., Juhl, C., and Hagerup, O. (1988) Evaluation of Inhibitors for Sour Crude Oil Transmission Pipe Lines. Paper 198, Corrosion 88, NACE, Houston.

[7] Britton, C. F. (1980) Monitoring Internal Corrosion in Offshore Installation. Corro. Prevo Cont., Vol. 27, No.2, pp. 10-12.

[8] Jasinski, R., and Efird, K. D. (1988) Electrochemical Corrosion Probe for High Resistivity Hydrocarbon-Water Mixtures. Corrosion, Vol. 44, No.9, pp. 658-663.

[9] Jaske, C. E., Beavers, J. A. and Thompson, N. G. (1995) Improving Plant Reliability through Corrosion Monitoring. Fourth International Conference on Process Plant Reliability. Houston Texas. Organized by Gulf Publishing Company and Hydrocarbon Processing.

[10] Talbot, D. E. J. and Talbot, J. D. R. (1998) Corrosion Science and Technology. CRC Press LLC, Florida. 